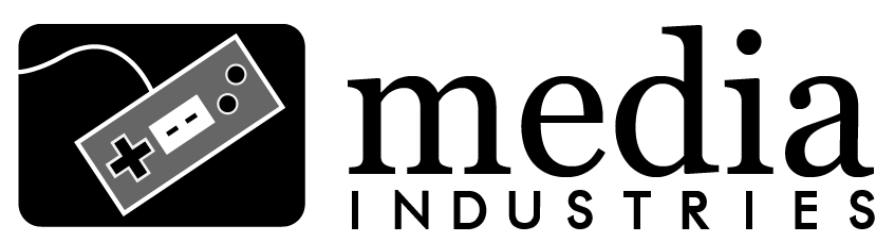

\title{
Placing International Media Production
}

\author{
Aphra Kerr ${ }^{1}$ \\ National University of Ireland Maynooth \\ aphra.kerr [AT] nuim.ie
}

\begin{abstract}
:
Studies of contemporary media production have to grapple with the empirical, methodological, and theoretical challenges of internationalization. While cultural imperialism and the new international division of cultural labor theories have highlighted important power differentials internationally, they often lack empirical depth and focus on large traditional media companies and national, particularly Western, countries. In this short essay I consider how "spatialization" and the social production of space might provide a useful theoretical approach for studying international contemporary media production practices. I illustrate my argument by contrasting findings from empirical research on the factors shaping the spatialization of the digital games and broadcast animation industries: one an emerging industry struggling to legitimate its cultural standing and build international networks of production; the other a well-established cultural industry tied into national cultural policies and networks of production. An industry focus and relational approach to space allows us to capture the dynamic tension between international flows (of ideas, products, services, workers, and money) and the practices (policy, regulation, institutions, markets, technology, and content) that attempt to capture these flows in particular places.
\end{abstract}

Keywords: Gaming, Globalization, Labor, Production, Political Economy

\section{Understanding Space and Place}

While much of the globalization literature talks of deterritorialization, transnationalism, and global flows, we are seeing at the same time more locational competition and attention being paid to aspects of place and/or space. When I use these terms, it is not in any absolute sense. Rather it is relational and, in terms of cultural production, it means that we need to investigate how and in what ways industries, companies, workers, texts, and users get embedded in particular spaces while simultaneously being involved in global flows. It is to question why a company has located in $X$ or moved its production to $Y$ and if and, in what ways, are the company and their products localized and particular. It is also to note that space and place are experienced both objectively and subjectively-thus companies and workers in the same industry and located in the same city may experience that city quite differently. 
This is not a unique perspective. It is, of course, prevalent in more critical and feminist geography but it also appears to varying degrees in media scholarship. In scholarship on the creative industries in the UK, there has been a lot of work that argues for increased sensitivity to spatial and locational factors. ${ }^{2}$ In media and communications fields, there is a tradition that explores cross-national geo-cultural and geo-linguistic markets and regional flows. ${ }^{3}$ And of course there is the work on a new industrial division of cultural labor. ${ }^{4}$ More recently, Vincent Mosco identifies spatialization as a core starting point for any analysis of communication. ${ }^{5}$

Yet the focus on space and place needs some more theoretical development. Mosco draws upon the work of Henri Lefebvre, but still mainly attends to the structure and actions of corporations and states. As I have argued elsewhere, Lefebvre has a richer conceptualization of the social production of space, one that connects the symbolic and representational to practice. ${ }^{6}$ Lefebvre stresses the need to attend to the interrelationship between three aspects: spatial practices, representations of space (i.e., formal abstractions like maps), and representational spaces (i.e., lived experiences and actions). ${ }^{7}$ For Lefebvre, we must attend to the social, cultural, and everyday lived experiences of people in space.

While Lefebvre's initial work was conducted almost forty years ago in France, it can be productively applied to the study of mobile companies, work, and workers in the context of media capitals and new national and supranational entities (e.g., the EU and Asia-Pacific). However, we need to consider the methodological and theoretical implications of attending to varying spatialities and processes of spatialization. Is it sufficient to compare industries within a country or between two countries? When does a multinational company become a local one? What is the relationship between space, place, and power?

\section{Examples}

One can usefully explore space, place, and power through the contemporary digital games industry. To some authors, this is the foremost example of a frictionless post-Fordist informational and promotional capitalism. ${ }^{8}$ While clearly it produces informational products and services, the digital games industry has disparate international hardware and software production networks and displays a lot of variance across and within markets. ${ }^{9}$ These differences are reinforced by the establishment of technological and organizational regions, like the EMEA region for Europe, the Middle East, and Africa. Within this framework, there are linguistic and other market distinctions. Add increasing competition between states, regions, and cities to attract transnational game companies and you start to see the active social production of spaces. ${ }^{10}$ This process is now extending to game content as state support gets tied to national and regional cultural values-a development about which the industry is ambiguous.

It would be inaccurate, therefore, to presume that there is a freely operating global market in digital games and that their development, distribution, and circulation are "footloose." Particular urban locations appear to be important for publishers. While development and support companies can take advantage of technological changes to locate their operations anywhere, we are still seeing that they prefer to be located in or near major urban markets. Increasingly, these companies locate in cities where other advantages are outweighing the locational costs, or where regional, national, or local subsidies have reduced their costs. Thus, the spatial distribution of the games industry is complex and linked in part to the history of the 
games industry but more significantly to the regional structure of software production networks interacting with local and regional financial, cultural, and labor markets. As this industry moves towards games as a service rather than simply a product, it is actively negotiating where, when, and for how long it locates in particular places.

One of the first to point to the spatial variations across the value chain of the digital games industry was Jennifer Johns. ${ }^{11}$ She noted how finance, uneven power relations between actors in the production network, and cultural embeddedness contribute to the creation of "regional games software production networks." In Ireland, research has found unequal access to state incentives between foreign-owned multinational game companies and locally established startups, and between companies involved in production and companies involved in services. In the main, foreign-owned multinational companies engaged in labor-intensive services and community support had better access to state support than local start-ups. Content production is seen as a more risky investment than community support. ${ }^{12}$

Yet, an industrial policy that focuses on attracting mobile multinationals engaged in game services and support is also risky. Surveys of employment in the Irish game industry have found a lot of fluctuation in numbers of employees. In the past three years, Ireland has seen the closure of branches of PopCap and Big Fish games companies as high-tech jobs have been cut due to restructuring in what are, in fact, profitable companies. EA also reduced the number of community support employees in Ireland due to worse-than-expected European player numbers in some of their games. The level of embeddedness of these foreign-owned companies is relatively low but they have all benefitted from state incentives to locate in Ireland.

Finally, we must contend with cultures of production. An important corrective to statistical generalizations are ethnographic studies conducted within game companies or interviews with game company staff, freelancers, and interns. These studies provide important nuance to the image of the digital games production industry as a young, white, mostly-male industry with problematic project management practices and workplace culture. These studies highlight variations between small start-ups, established multinationals, and large indigenous companies. Local start-ups that are acquired by multinational businesses offer another interesting challenge to our assumptions about media ownership as they often, in fact, retain their local managers, linkages, and culture.

An instructive comparison can be made with production processes in broadcast animation companies. In a recent study, we researched a production project from inception to completion and followed the production networks across companies, borders, and continents. In an established cultural industry with a complex set of national and cross-national co-production financing structures as well as variations in local content regulations and regional selling markets, we quickly realized that there were multiple spatialities at work. However, while the production projects sourced their ideas, finance, and labor internationally, they were limited to working with companies in countries where co-production agreements existed, while making use of local specificities to purposefully and productively vary the content. In this case, we are looking at a multi-scalar geography of cultural production shaped by national institutional, cultural, and financial structures. The animation industry developed a range of state, local, and regional supports to offset the risks involved in creative production. These supports were based on the cultural value of animation and were in contrast to the games industry in Ireland, whose funding is mostly based on employment and potential revenue. (Uniquely to date in Europe, France has introduced a tax credit system for games production based on a cultural test.) 
While it could be said that we found a high degree of internationalization and distanciated cooperation in these animation projects, this finding was not uniform across the production process. Transnational collaboration in creative conceptualization and financing occurred mainly with the UK, Canada, and the US and relied on a shared language, cultural heritage, and other forms of proximity. ${ }^{13}$ This was in marked contrast to more labor-intensive elements of the production process that were outsourced to the Philippines and which received less creative and managerial input. Again we see that cultural production is spatially distributed, but this distribution is structured by a range of historic, economic, social, and cultural factors.

To empirically understand contemporary international cultural industries, it is necessary to critically examine representations of/by the industry, the structure and boundaries of the industry, and its locational politics. Little independent data exists about the digital games industry; and it is ill-defined. Currently, institutions, including international and national trade associations as well as local and regional governments, are actively trying to legally define and place the digital games industry as they have previously done with the animation, film, and television industries. These institutional struggles should be a key focus of empirical attention. To empirically study production it is also necessary to rethink our methodological approaches. We must look beyond the company and the nation-state and follow the product or service through the various institutional and social networks that shape its spaces of production and consumption. We must examine the spatialization of projects from design through to production and circulation/support; and as the cultural industries increasingly produce services, we must reevaluate the attention paid to "circulation." Production involves a range of practices and creative workers but these concepts are evolving and should not be taken for granted.

1 Aphra Kerr is a senior lecturer in the Department of Sociology at NUI Maynooth, Ireland. She has extensive research experience with a focus on the international digital games, animation, and television industries. She has previously been a visiting professor at the Annenberg School for Communication at the University of Pennsylvania and worked as a full-time researcher in the UK and the Netherlands. She has consulted for the European Commission and the Organization for Economic Cooperation and Development (OECD). For more, visit her webpages.

2 Andy C. Pratt, Rosalind Gill, and Volker Spelthann, "Work and the City in the eSociety: A Critical Investigation of the Sociospatially Situated Character of Economic Production in the Digital Content Industries in the UK," Information, Communication and Society 10, no. 6 (2008): 922-942; Mark Banks, The Politics of Cultural Work (New York: Palgrave Macmillan, 2007).

3 David Hesmondhalgh, The Cultural Industries, 2nd ed. (London: Sage, 2007); Paschal Preston and Aphra Kerr, "Digital Media, Nation-States and Local Cultures: The Case of Multimedia 'Content' Production," Media, Culture and Society 23, no. 1 (2001): 109131; Marwan M. Kraidy and Omar Al-Ghazzi, “Neo-Ottoman Cool: Turkish Popular Culture in the Arab Public Sphere," Popular Communication 11, no. 1 (2013): 17-29.

4 Toby Miller, "The New International Division of Cultural Labour," in Global Hollywood, eds. Toby Miller, Nitin Govil, John McMurria, Ting Wang, and Richard Maxwell (London: BFI, 2005).

5 Vincent Mosco, The Political Economy of Communication, 2nd ed. (London: Sage, 2009). 
6 Aphra Kerr and Anthony Cawley, "The Spatialisation of the Digital Games Industry: Lessons from Ireland," International Journal of Cultural Policy 18, no. 4 (2012): 398-418.

7 Henri Lefebvre, The Production of Space/Production de L'espace (Oxford: Blackwell, 1991).

8 Stephen Kline, Nick Dyer-Witheford, and Greig De Peuter, Digital Play: The Interaction of Technology, Culture and Marketing (Montreal: McGill-Queen's University Press, 2003).

9 Randy Nichols, "Who Plays, Who Pays? Mapping Video Game Production and Consumption Globally," in Gaming Globally: Production, Play and Place, eds. Nina Huntemann and Ben Aslinger (New York Palgrave Macmillan, 2013), 19-39.

10 Aphra Kerr, "Space Wars: The Politics of Games Production in Europe," in Gaming Globally, eds. Nina Huntemann and Ben Aslinger (New York: Palgrave, 2013), 215-231.

${ }^{11}$ Jennifer Johns, "Video Games Production Networks: Value Capture, Power Relations and Embeddedness," Journal of Economic Geography 6, no. 2 (2006): 151-180.

12 Kerr and Cawley, "The Spatialisation of the Digital Games Industry," 398-418.

${ }^{13}$ Chris van Egeraat, Sean O'Riain, and Aphra Kerr, "Social and Spatial Structures of Innovation in the Irish Animation Industry," European Planning Studies 21, no. 9 (2013): 1-19.

\section{Bibliography}

Banks, Mark. The Politics of Cultural Work. New York: Palgrave Macmillan, 2007.

Dyer-Witheford, Nick, and Zena Sharman. "The Political Economy of Canada's Video and Computer Game Industry" Canadian Journal of Communication 30 (2005): 187-210.

Hesmondhalgh, David. The Cultural Industries. 2nd ed. London: Sage, 2007.

Johns, Jennifer. "Video Games Production Networks: Value Capture, Power Relations and Embeddedness." Journal of Economic Geography 6, no. 2 (2006): 151-180.

Kerr, Aphra. "Space Wars: The Politics of Games Production in Europe."In Gaming Globally, edited by Nina Huntemann and Ben Aslinger, 215-231. New York: Palgrave, 2013.

Kerr, Aphra, and Anthony Cawley. "The Spatialisation of the Digital Games Industry: Lessons from Ireland."International Journal of Cultural Policy 18, no. 4 (2012): 398-418.

Kline, Stephen, Nick Dyer-Witheford, and Greig De Peuter. Digital Play: The Interaction of Technology, Culture and Marketing. Montreal: McGill-Queen's University Press, 2003.

Kraidy, Marwan M., and Omar Al-Ghazzi. "Neo-Ottoman Cool: Turkish Popular Culture in the Arab Public Sphere." Popular Communication 11, no. 1 (2013): 17-29.

Lefebvre, Henri. The Production of Space/Production de L'espace. Oxford: Blackwell, 1991.

Miller, Toby. "The New International Division of Cultural Labour." In Global Hollywood, edited by Toby Miller, Nitin Govil, John McMurria, Ting Wang, and Richard Maxwell. London: BFI, 2005.

Mosco, Vincent. The Political Economy of Communication. 2nd ed. London: Sage, 2009.

Nichols, Randy. "Who Plays, Who Pays? Mapping Video Game Production and Consumption Globally."In Gaming Globally: Production, Play and Place, edited by Nina Huntemann and Ben Aslinger, 19-39. New York: Palgrave Macmillan, 2013. 
Pratt, Andy C., Rosalind Gill, and Volker Spelthann. "Work and the City in the e-Society. A Critical Investigation of the Sociospatially Situated Character of Economic Production in the Digital Content Industries in the UK." Information, Communication and Society 10, no. 6 (2008): 922-942.

Preston, Paschal, and Aphra Kerr. "Digital Media, Nation-States and Local Cultures: The Case of Multimedia 'Content' Production." Media, Culture and Society 23, no. 1(2001): 109-131.

van Egeraat, Chris, Sean O'Riain, and Aphra Kerr. "Social and Spatial Structures of Innovation in the Irish Animation Industry." European Planning Studies 21, no. 9 (2013): 1-19.

\section{(cc) $)$ EY-NC-ND}

Copyright $\odot 2014$ (Aphra Kerr). Media Industries is an open-access, peer-reviewed, online academic journal. As such, we aim to participate in the open exchange of information. This work is licensed under a Creative Commons Attribution Noncommercial No Derivatives (by-nc-nd) License. Under this license, this work is available for sharing and noncommercial distribution provided the appropriate attribution is given. 